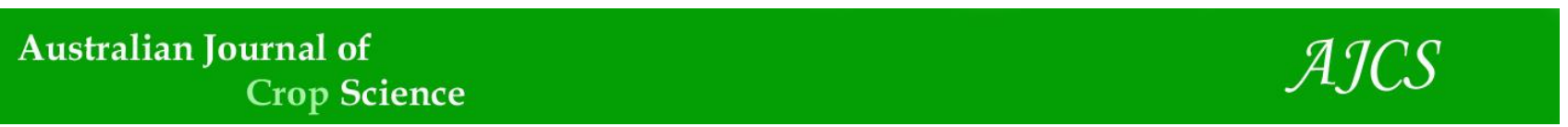

AJCS 14(09):1443-1448 (2020)

ISSN:1835-2707

doi: 10.21475/ajcs.20.14.09.p2466

\title{
Root and shoot growth in safflower as affected by soil compaction
}

\author{
Caroline Beal Montiel ${ }^{1 *}$, Deonir Secco ${ }^{1}$, Araceli Ciotti Marins ${ }^{1}$, Luiz Antônio Zanão Junior ${ }^{1,2}$, Jeikson Rafael \\ Deggerone $^{1}$, Doglas Bassegio ${ }^{1}$
}

1'Universidade Estadual do Oeste do Paraná, UNIOESTE, CEP 85819130, Cascavel, PR, Brazil
${ }^{2}$ Agronomic Institute of Paraná, IAPAR, CEP 85825000, Santa Tereza do Oeste, Paraná, Brazil

*Corresponding author: caroline_montiel@hotmail.com

\begin{abstract}
Soil compaction, induced by no-tillage practices, can negatively impact soil properties important for plant growth. Compacted soils can restrict root growth depth, resulting in reduced crop yield. Although safflower (Carthamus tinctorius) has a deep root system, yield may still be affected by soil compaction. Therefore, this study aimed to evaluate safflower root and shoot growth when submitted to soil compaction in an Oxisol soil under controlled (greenhouse) and field conditions. Five soil bulk density measures were performed in a greenhouse $\left(1.1,1.2,1.3,1.4\right.$ and $1.5 \mathrm{Mg} \mathrm{m}^{-3}$ ). Four compaction levels (established by the number of passes of a farm tractor: $0,1,3$, and 5 passes consecutively) were performed to evaluate the effect of soil compaction in the field. Root and shoot growth were measured after harvesting the plants. Safflower root growth was reduced when soil compaction increased from 1.1 to $1.5 \mathrm{Mg} \mathrm{m}^{-3}$ under controlled (greenhouse) conditions. In field conditions, we observed a decrease in root length, and fresh and dry matter in roots and shoots of safflower as the soil compaction increased to $5 \mathrm{P}\left(1.28 \mathrm{Mg} \mathrm{m}{ }^{-3}\right)$. The results of our study suggest safflower root and shoot growth can be impacted by soil compaction which could affect crop yield.
\end{abstract}

Keywords: Carthamus tinctorius L.; density; soil compaction; oilseeds.

Abbreviations: SOM_Soil organic matter; BS_Base saturation; P_tractor passes.

Introduction

The demand for biofuel production has increased in more recent times due to a combination of factors; possible exhaustion of oil supplies, resulting in increasing oil prices, and the impacts that fossil fuels have on the environment, namely the green-house effect, are likely drivers. The increased demands on biofuel production have led to the need to be able to produce biofuel seed oil across multiple seasons. Therefore 'alternative' oilseed crops, such as safflower (Carthamus tinctorius), which are more tolerant to abiotic stresses characteristic of tropical climates, are now been utilized (Movahedy-Dehnavy et al., 2009, Santos et al., 2018). Safflower oil has high levels of oleic acid (30\%) and linoleic acid (70\%) and can be used as a feedstock for biodiesel production (llkılıç et al., 2011).

In Brazil, safflower is used as an option for the second annual crop (autumn-winter), during a seasonal period which characteristically has irregular rainfall (Santos et al., 2018). Although this species has the potential for cultivation in drier conditions (Lovelli et al., 2007; Santos et al., 2017), its yield may still be affected by other environmental variables such as soil compaction. Soil compaction is one of the main known causes of soil degradation (Roque et al., 2010). It typically occurs as a result of heavy usage of agricultural machinery and equipment (Lima et al., 2013) causing serious limitations on plant development in affected soils.

Compacted soil layers increase overall soil resistance, restricting root penetration and therefore root growth depth of plants, consequently hindering access to groundwater
(Chen et al., 2014; Nosalewicz and Lipiec, 2014). Due to root growth restriction, morphological changes such as increased root diameter and formation of twisted roots can occur (Silva and Rosolem, 2001; Sarto et al., 2018; Bassegio et al., 2018). However, species differ in their ability to overcome compacted soil layers, due to differences in soil pore size and root diameter (Rose et al., 2009).

Safflower has a deep root system that can enable this species a higher tolerance when subjected to soil compaction (Feizi et al., 2010). Several studies have been conducted using PVC rings to determine safflower tolerance to soil compaction (Paludo et al., 2017; Paludo et al., 2018; Sarto et al., 2018). However, few studies have investigated the effect of compaction on safflower growth under field conditions. Therefore, this study aimed to evaluate safflower root and shoot growth when submitted to soil compaction in an Oxisol soil.

\section{Results and discussion}

\section{Soil compaction under controlled conditions}

Soil compaction levels significantly affected $(p<0.01)$ safflower root growth in the controlled (greenhouse) experiment (Fig. 1). Root length, and fresh and dry root matter, was linearly reduced with increasing levels of soil compaction (Fig. 1A, B and C). The observed growth 
Table 1. Bulk density (BD), total porosity (TP), macroporosity e microporosity in layers of $0-0.1,0.1-0.2$, and $0.2-0.3 \mathrm{~m}$ depth affected by soil compaction by tractor passes (P).

\begin{tabular}{|c|c|c|c|c|}
\hline \multirow{2}{*}{ Tractor passes } & \multicolumn{4}{|c|}{ Macroporosity } \\
\hline & $\mathrm{BD}\left(\mathrm{Mg} \mathrm{m}^{-3}\right)$ & TP (\%) & $(\%)$ & Microporosity (\%) \\
\hline & \multicolumn{4}{|c|}{ Layer 0-0.1 m } \\
\hline$O P$ & $1.23 \mathrm{a}$ & $49.12 \mathrm{a}$ & $13.19 \mathrm{a}$ & $35.94 \mathrm{a}$ \\
\hline $1 \mathrm{P}$ & $1.30 \mathrm{a}$ & $46.02 \mathrm{a}$ & $10.04 \mathrm{~b}$ & $35.98 a$ \\
\hline $3 P$ & $1.34 \mathrm{a}$ & $44.57 \mathrm{a}$ & $9.52 b$ & $35.05 \mathrm{a}$ \\
\hline \multirow[t]{2}{*}{$5 \mathrm{P}$} & $1.32 \mathrm{a}$ & $45.56 \mathrm{a}$ & $9.71 b$ & $35.85 \mathrm{a}$ \\
\hline & \multicolumn{4}{|c|}{ Layer $0.1-0.2 \mathrm{~m}$} \\
\hline $0 P$ & $1.17 \mathrm{a}$ & $54.46 \mathrm{a}$ & $9.39 \mathrm{a}$ & $45.07 \mathrm{a}$ \\
\hline $1 \mathrm{P}$ & $1.20 \mathrm{ab}$ & $53.24 a b$ & $9.96 \mathrm{a}$ & $43.28 \mathrm{a}$ \\
\hline $3 P$ & $1.22 \mathrm{ab}$ & $52.34 a b$ & $9.97 \mathrm{a}$ & $42.37 \mathrm{ab}$ \\
\hline \multirow[t]{2}{*}{$5 \mathrm{P}$} & $1.28 \mathrm{~b}$ & $50.03 \mathrm{~b}$ & $11.12 \mathrm{a}$ & $38.91 \mathrm{~b}$ \\
\hline & \multicolumn{4}{|c|}{ Layer $0.2-0.3 \mathrm{~m}$} \\
\hline$O P$ & $1.13 \mathrm{a}$ & $58.42 \mathrm{a}$ & $11.17 \mathrm{a}$ & $47.25 \mathrm{a}$ \\
\hline $1 \mathrm{P}$ & $1.18 \mathrm{ab}$ & $56.59 a b$ & 10.09 a & $46.49 \mathrm{a}$ \\
\hline $3 P$ & $1.24 b$ & $54.50 \mathrm{~b}$ & $13.26 \mathrm{a}$ & $41.24 \mathrm{~b}$ \\
\hline $5 \mathrm{P}$ & $1.25 b$ & $53.55 \mathrm{~b}$ & $10.24 \mathrm{a}$ & $43.50 \mathrm{ab}$ \\
\hline
\end{tabular}

Table 2. Root length, root fresh matter, root dry matter, shoot fresh matter and root dry matter of safflower as affected by soil compaction by tractor passes $(\mathrm{P})$.

\begin{tabular}{|c|c|c|c|c|c|}
\hline Tractor passes & Root length $(\mathrm{cm})$ & $\begin{array}{c}\text { Root fresh matter } \\
(\mathrm{g})\end{array}$ & $\begin{array}{c}\text { Root dry matter } \\
\text { (g) }\end{array}$ & $\begin{array}{c}\text { Shoot fresh } \\
\text { matter }(\mathrm{g})\end{array}$ & Shoot dry matter (g) \\
\hline $0 P$ & $11.60 \mathrm{a}$ & $3.06 \mathrm{a}$ & $1.40 \mathrm{a}$ & $34.69 \mathrm{a}$ & $10.53 \mathrm{a}$ \\
\hline $1 \mathrm{P}$ & $5.76 b$ & $2.56 \mathrm{a}$ & $1.23 a b$ & $33.36 \mathrm{a}$ & $10.22 \mathrm{a}$ \\
\hline $3 P$ & $3.54 \mathrm{c}$ & $3.17 \mathrm{a}$ & $1.32 \mathrm{a}$ & $22.11 b$ & $6.45 b$ \\
\hline $5 P$ & $2.92 \mathrm{c}$ & $2.32 \mathrm{a}$ & $0.87 \mathrm{~b}$ & $20.24 \mathrm{~b}$ & $5.76 \mathrm{~b}$ \\
\hline
\end{tabular}

Values represented by the different letters, in each column show significant differences (Tukey test, $\mathrm{P}<0.05$ ).

Table 3. Soil chemical characteristics in the experimental areas before initiating the experiment.

\begin{tabular}{|c|c|c|c|c|c|c|c|c|}
\hline $\begin{array}{l}\mathrm{pH} \\
\left(\mathrm{CaCl}_{2}\right) \\
\end{array}$ & SOM+ & $P$ (resin) & $\mathrm{H}+\mathrm{Al}$ & $\begin{array}{c}\text { Exchangeable } \\
\mathrm{K}\end{array}$ & $\begin{array}{c}\text { Exchangeable } \\
\mathrm{Ca} \\
\end{array}$ & $\begin{array}{c}\text { Exchangeable } \\
\mathrm{Mg}\end{array}$ & & BS \\
\hline & $\mathrm{dm}_{3}^{-}$ & $\underset{3}{\mathrm{dm}^{-}}$ & & ------- & $\mathrm{nol}_{\mathrm{c}} \mathrm{dm}^{-3}---$ & --- & $\%$ & \\
\hline 5.0 & 32 & 9.4 & 6.2 & 0.33 & 5.2 & 2.9 & & 58 \\
\hline
\end{tabular}

+ Soil organic matter.‡ Base saturation.

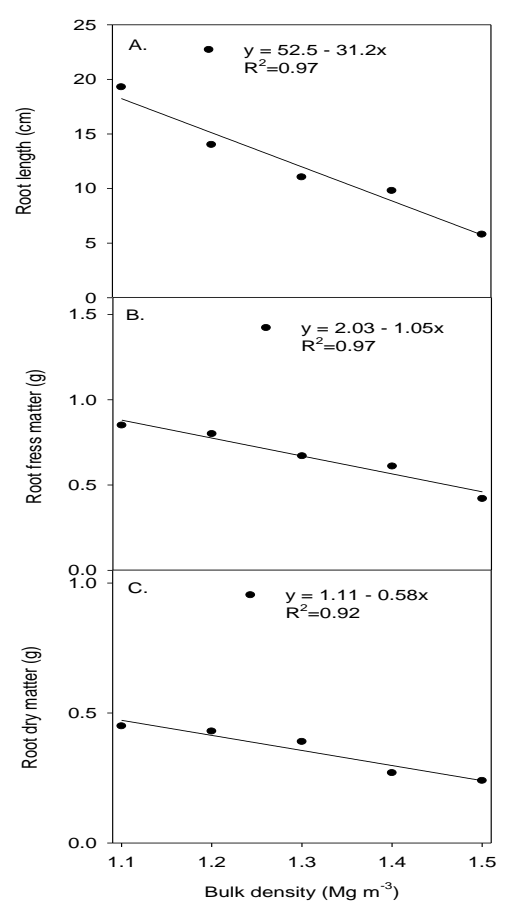

Fig. 1. Root length (A), root fresh matter (B) and root dry matter (C) of safflower affected by soil bulk density. Significant at $P<0.05$ probability. 

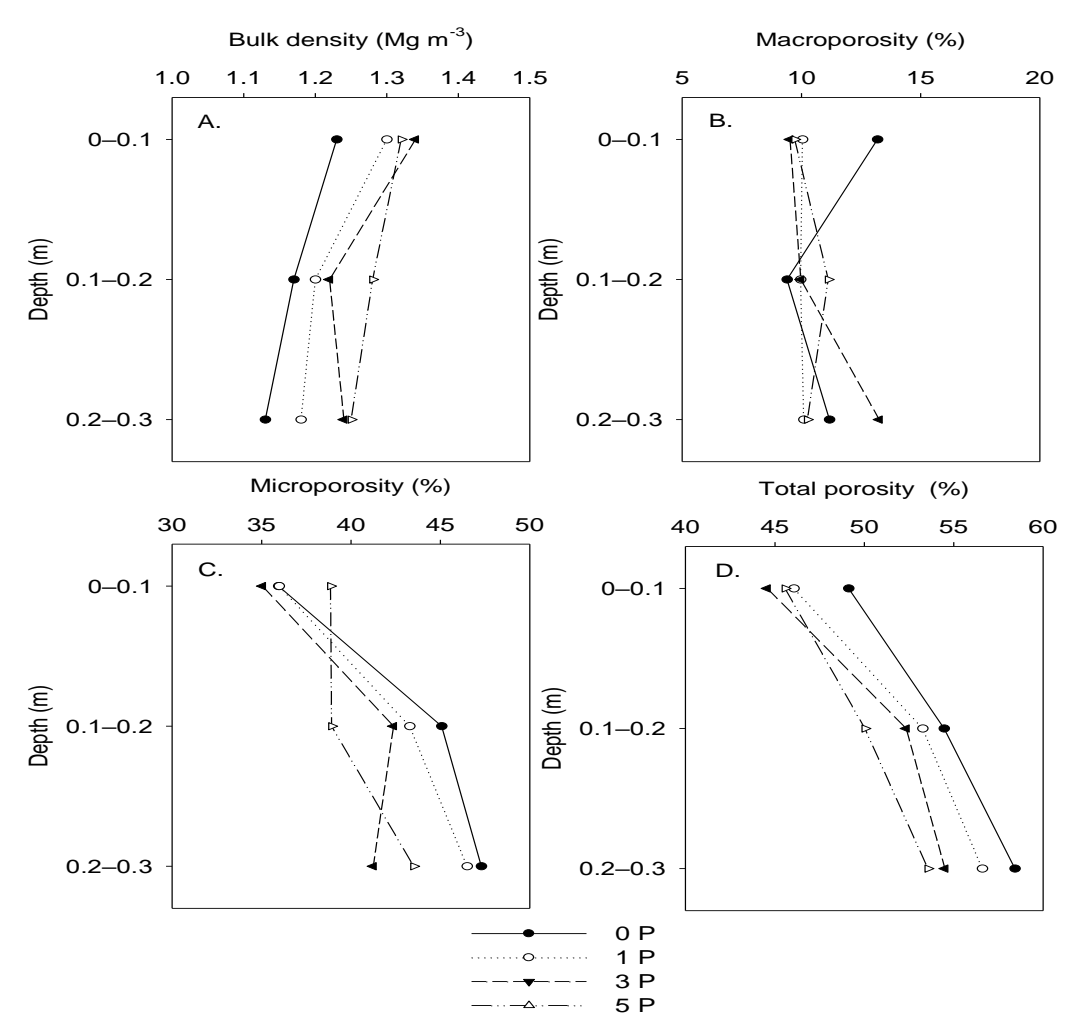

Fig 2. Bulk density (A), macroporosity (B), microporosity (C) and total porosity (D) affected by tractor passes (P).

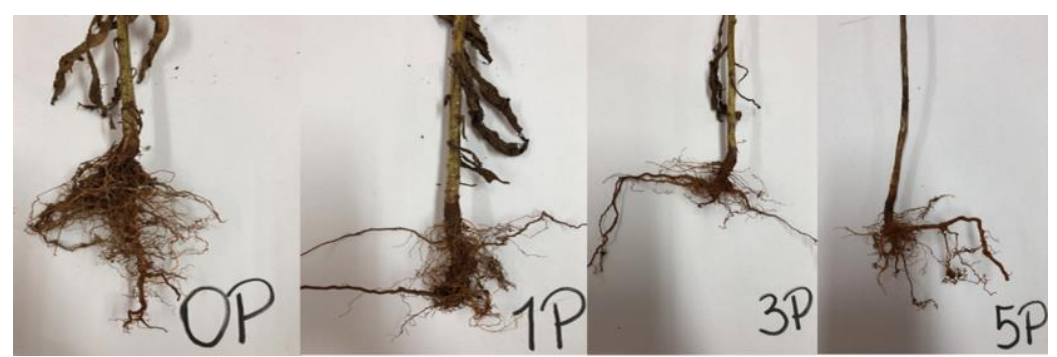

Fig 3. Safflower root architecture affected by soil compaction. $P=\operatorname{Tractor}$ passes $(0,1,3$, and 5$)$.

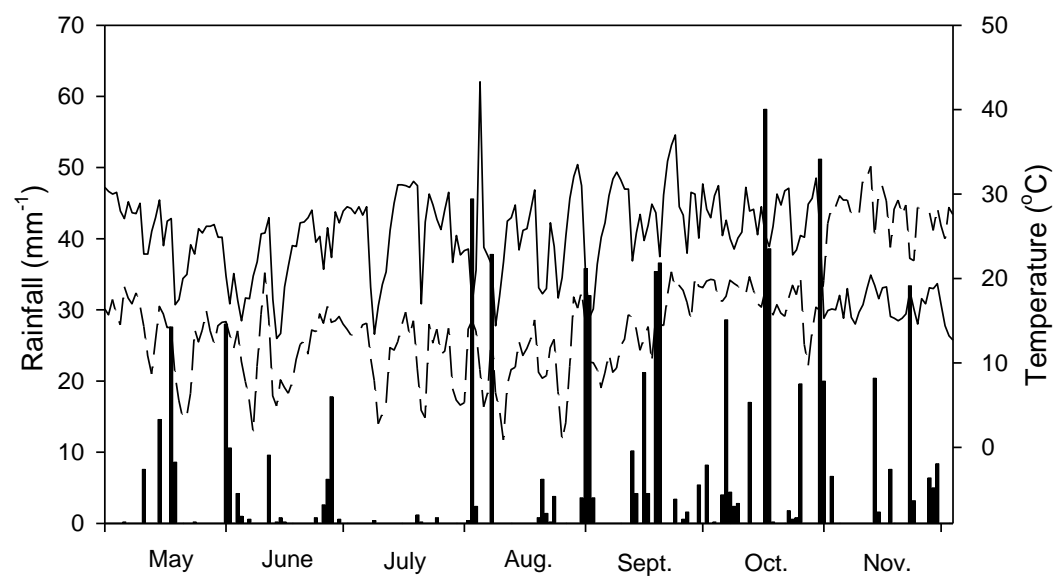

Fig 4. Behavior of meteorological variables of precipitation and mean temperature during safflower cultivation.

reduction suggests deep root growth was restricted in more compacted soil conditions (Sarto et al., 2018). This result is in keeping with the research findings of Reichert et al. (2009), which showed soil density values $>1.35 \mathrm{Mg} \mathrm{m}^{-3}$ for clayey soils, restrict root growth of some agricultural crops. Compacted soils often cause a reduction in root growth due to a reduced volume of soil been utilized by the plants root system, aerial growth and development of the plant can be negatively affected as a result (Rosolem et al., 2002; Sarto et al., 2018).

In order to adapt to increased penetration resistance levels in compacted soils, the plants roots undergo morphological 
and physiological changes that vary depending on the species, or genotype of the plant (Materechera et al., 1992). Other studies have shown similar findings; maize in a medium texture Distroferric Red Latosol soil (1.28 to 1.68 $\mathrm{Mg} \cdot \mathrm{m}^{-3}$ ) (Foloni et al., 2003), and soybean in a clay-textured Red Nitosol soil (0.26 to $1.98 \mathrm{MPa}$ ) (Foloni et al., 2006) demonstrated root dry matter effects specific to cultivar or genotype.

These results corroborate the findings of a study by Sarto et al. (2018) that investigated different safflower genotypes submitted to varying soil densities; with an increase in density there was a reduction in the values of root dry matter obtained, and this reduction was more significant when the soil density was $1.6 \mathrm{Mg} \mathrm{m}^{-3}$. Interestingly, in another study investigating different genotypes of safflower in compacted soils the critical soil density level for crop growth was, on average, $1.2 \mathrm{Mg} \mathrm{m}^{-3}$ (Paludo et al., 2017). The authors also found that the observed differences appeared to vary between genotypes.

\section{Soil compaction under field conditions}

Significant differences $(p<0.05)$ were found between macropores in the $0-0.1 \mathrm{~m}$ soil layer. Macropore volume was significantly higher in uncompacted soil $(\mathrm{OP}=13.10 \%)$ compared to compacted soil treatments $(1 \mathrm{P}=10.04 \%, 3 \mathrm{P}=$ $9.52 \%$ and $5 \mathrm{P}=9.71 \%$ ) (Table 1 ; Fig. $2 \mathrm{~B}$ ). In a study by Junior et al. (2012) investigating the effects of different compaction levels on latosol soil, soil density values increased with increased tractor passes. The researchers also found there was a reduction in macroporosity in the $0-0.1 \mathrm{~m}$ soil layer.

Notably, significant difference $(p<0.05)$ was observed between the different soil treatments in the 0.1-0.2 $\mathrm{m}$ layer for the current study. Was observed an increase in soil density (Fig. 2A), reduction of the total soil porosity (Fig. 2D), and the volume of micropores (Fig. $2 \mathrm{C}$ ) in the $0.1-0.2 \mathrm{~m}$ soil layer when the soil was compacted with 5 tractor passes (5P) (Table 1). This finding contrasts with that of Scapinelli et al. (2016) which found there was a significant difference in the volume of macropores in the $0.10-0.15 \mathrm{~m}$ layer after the soil was compacted.

In the 0.2-0.3 m layer, it was observed that the OP treatment presented lower density values for the $3 \mathrm{P}$ and $5 \mathrm{P}$ soil treatments (Fig. 2A). There was also a reduction in the values for volume of micropores (Fig. $2 \mathrm{C}$ ) and the total porosity (Fig. 2D). This suggests the weight of the tractorsprayer set negatively affected these physical attributes of the soil to a depth of $0.2-0.3 \mathrm{~m}$ (Table 1; Fig. 2).

Safflower shoot and root growth was significantly affected $(p<0.05)$ by soil compaction under field conditions. It was observed that root length was reduced in the $1 \mathrm{P}, 3 \mathrm{P}$, and $5 \mathrm{P}$ compacted soil treatments compared to the $\mathrm{OP}$ control (Table 2).

The shorter root length observed in 5P compacted soils had negative effects on root dry matter and fresh and dry matter in roots and shoots (Table 2). Research on safflower genotypes conducted by Paludo et al. (2018) found that the critical soil density value for root dry matter was $1.04 \mathrm{Mg} \mathrm{m}^{-}$ 3. The authors also found that the measurement of increased soil density was reduced by up to $71 \%$ for the total root dry matter. Similar to the current study, decreases observed in the dry matter of shoot accumulation caused by penetration resistance are likely due to root aeration deficiency, which in a clay-textured Red Latosol begins with soil densities close to $1.30 \mathrm{Mg} \mathrm{m}^{-3}$ (Argenton et al., 2005; Sarto et al., 2018).
The current field experiment also showed there was a reduction in the average length of safflower roots under different soil compaction treatments $(3 \mathrm{P}=69 \%$ and $5 \mathrm{P}=$ $75 \%$; Table 2). These findings are similar to those found by Bergamin et al. (2010); a significant reduction in the growth of corn roots was observed with increasing levels of tractor passes. Another study by Valadão et al. (2015) also found higher traffic levels ( 8 tractor passes) negatively influenced the root growth of soybeans, as well as their distribution in the soil profile. The authors postulated this was likely owing to soil compaction levels causing an increase in resistance to soil penetration by plant roots. Additionally, it was thought that compaction would cause a reduction in macroporosity and total porosity of the soil. Interestingly, a study by Scapinelli et al. (2016) investigating sunflower growth in compacted soils found that physical soil changes caused by tractor traffic resulted in anatomical changes in the roots of plants after only three tractor passes.

Root restriction and confinement in the topsoil are accompanied by changes to the entire root system (Grzesiak et al., 2013; Pfeifer et al., 2014), as shown in Fig. 3. Compaction causes root thickening due to morphophysiological changes to the radicle system after entering the compacted layer (Ramos et al., 2010).

\section{Materials and methods}

\section{Study site description}

The controlled experiment was conducted at Western Paraná State University, at the Cascavel-PR campus $\left(24^{\circ} 59^{\prime} 21.2\right.$ "S 53²6'59.6 "W; altitude of $\left.781 \mathrm{~m}\right)$, from September to December 2017. This component of the study was undertaken in a green house. The Oxisol soil used in the study was collected from a depth of 0-0.2 $\mathrm{m}$, comprising a clayey to very clayey texture $\left(600 \mathrm{~g} \mathrm{~kg}^{-1}\right.$ of clay, $320 \mathrm{~g} \mathrm{~kg}^{-1}$ of silt and $80 \mathrm{~g} \mathrm{~kg}^{-1}$ of sand) (Embrapa, 1997), a soft undulating relief, and basalt substrate (Embrapa, 2018). Before starting the experiment, the chemical characteristics of the soil were determined (0-0.2 $\mathrm{m}$; Table 3 ) according to the methods of Embrapa et al. (2009).

\section{Treatments and experimental design}

Five soil compaction levels $\left(1.1,1.2,1.3,1.4\right.$ and $1.5 \mathrm{Mg} \mathrm{m}^{-}$ $\left.{ }^{3}\right)$ were used in the experiment. The study design was entirely randomized and involved four repetitions for each soil treatment. To prepare the PVC rings for the compacted layer, the mass required to fill the ring was calculated. The soil was then compacted by applying light pressure with an iron cylinder measuring the same internal diameter as the PVC rings (Sarto et al., 2018).

Pots were assembled using overlapping PVC rings with an internal diameter of $0.2 \mathrm{~m}$. The height of the top and bottom rings of the pots were $0.15 \mathrm{~m}$ and $0.3 \mathrm{~m}$ respectively, and the height of the intermediate ring, in which we placed the different soil treatments, was $0.5 \mathrm{~m}$. Seven saffron seeds were sown per pot to a depth of $0.3 \mathrm{~m}$. Thinning was applied once seedlings were visible, with only three plants kept per pot for the duration of the experiment. Each experimental unit received set irrigation in accordance with the evapotranspiration method proposed by Hargreaves and Samani (1985). 


\section{Traits evaluated}

The saffron plants were harvested from pots 113 days after initial sowing. Plants were extracted with the root mass attached; root systems were then washed with water immediately after removal to preserve the root system. Root length was measured at the main root of a plant using a graduated ruler. Roots were subsequently dried in an oven at $60{ }^{\circ} \mathrm{C}$ for a period of $48 \mathrm{~h}$ and the weight of the root system of each plant was recorded.

\section{Soil compaction under field conditions}

\section{Study site description}

The field component of the study was conducted at the Cascavel-PR campus of the Western Paraná State University in an outdoor area adjacent to the greenhouse used in the controlled component of the study, from May to September 2018. According to the Köppen classification, the climate of the site is of a subtropical Cfa type, without a defined dry season; the hottest period averages temperatures higher than $22{ }^{\circ} \mathrm{C}$ with the coldest month averaging below $18{ }^{\circ} \mathrm{C}$; with hot summers in winter and infrequent frosts. The meteorological variables for the experimental period are shown in Fig. 4.

The soil type used in the field experiment is classified as an Oxisol with a clayey to very clayey texture $\left(600 \mathrm{~g} \mathrm{~kg}^{-1}\right.$ of clay, $320 \mathrm{~g} \mathrm{~kg}^{-1}$ of silt and $80 \mathrm{~g} \mathrm{~kg}^{-1}$ of sand) (Embrapa, 1997), soft undulating relief, and basalt substrate (Embrapa, 2018). For the control component of the study, before starting the experiment, the chemical characteristics of the soil were determined (0-0.2 m; Table 3 ) according to the methods of Embrapa et al. (2009).

\section{Treatments and experimental design}

The experiment was conducted in an area of field, with four compaction levels (treatments) established by the number of passes $(0,1,3$, and 5 passes) of a farm tractor (New Holland $7630(76 \mathrm{~kW})$ ), with a full 700 -liter sprayer (Corisco 700 ) attached (total weight of $\cong 7.1 \mathrm{t}$ ). The field used for the four treatments comprised an area of $5 \times 3 \mathrm{~m}$, in which two rows of safflower seeds were sown with $0.6 \mathrm{~m}$ spacing between rows. Field planting was performed in March 2018; 33 seeds were sown per meter.

\section{Traits evaluated}

The harvest was performed 110 days after initial sowing. Using the same methods as for the controlled experiment, plants were extracted, together with the root mass, and were washed with water to preserve the entire extension of the root system. Root length was measured at the main root using a graduated ruler. The roots were then dried in an oven at $60^{\circ} \mathrm{C}$ for a 48 -hour period and their dry weight was recorded. Plant shoots were also dried in an oven at $60{ }^{\circ} \mathrm{C}$ but for an extended period of 72 hours.

After harvesting of safflower plants, soil samples were collected for soil physical characterization, in which the; bulk density, total porosity, microporosity, and macroporosity of the soil were determined. Samples were collected from opened trenches for each experimental plot and undisturbed samples were collected using volumetric stainless-steel rings with a volume of approximately $98 \mathrm{~cm}^{3}$ ( $0.5 \mathrm{~m}$ in diameter and $0.5 \mathrm{~m}$ in height) from three soil layers
$(0-0.1,0.1-0.2$, and $0.2-0.3 \mathrm{~m})$, with the aid of a soil hammer and a soil extractor. The procedures for calculating these physical attributes followed the methodology recommended by Embrapa (1997).

\section{Statistical analyses}

Data were analyzed using analysis of variance (ANOVA). For experiments under controlled conditions, regression analysis was performed (significance level $=0.05$ ). For experiments in field conditions, a Tukey test was performed (significance level $=0.05$ ). Statistical analyses were conducted with SISVAR version 5.6.

\section{Conclusions}

Safflower root growth decreased when soil compaction increased ranging from 1.1 to $1.5 \mathrm{Mg} \mathrm{m}^{-3}$ under controlled (greenhouse) conditions. In field conditions, we observed a reduction in root length, root dry matter, and fresh and dry matter in roots and shoots of safflower as the soil compaction increased to $5 \mathrm{P}\left(1.28 \mathrm{Mg} \mathrm{m}^{-3}\right)$. Soil compaction in no-tillage is important under subtropical conditions due to the severe rates of decomposition of crop residues. In this sense, safflower has been shown to have some sensitivity to soil compaction.

\section{Acknowledgments}

The authors thank CAPES (Coordenação de Aperfeiçoamento de Pessoal de Nível Superior) for financial support

\section{References}

Argenton J, Albuquerque JA, Bayer C and Wildner, LP (2005) Comportamento de atributos relacionados com a forma da estrutura de Latossolo Vermelho sob sistemas de preparo e plantas de cobertura. Rev. Bras. Ciênc. Solo. 29:425-435.

Bassegio D, Sarto MVM, Rosolem CA, Sarto JRW (2018) Guar root and shoot growth as affected by soil compaction. Pesqui Agropecu Trop. 48:163-169.

Bergamin AC, Vitorino ACT, Franchini JC, Souza CMA, Souza FR (2010) Compactação em um Latossolo Vermelho distroférrico e suas relações com o crescimento radicular do milho. Rev Bras Ciênc Solo. 34:681-691.

Chen G, Weil RR, Hill RL (2014) Effects of compaction and cover crops on soil least limiting water range and air permeability. Soil Till Res. 136:61-69.

Clark LJ, Whalley WR, Barraclough PB (2003) How do roots penetrate strong soil? Plant Soil. 255:93-104.

Embrapa - Empresa Brasileira de Pesquisa Agropecuária (2018) Sistema Brasileiro de Classificação de Solos. 5. ed. Brasília.

Embrapa - Empresa Brasileira de Pesquisa Agropecuária (1997) Manual de métodos de análise de solo: Centro Nacional de Pesquisa de Solos (2nd ed.). Rio de Janeiro: Embrapa.

Embrapa - Empresa Brasileira de Pesquisa Agropecuária (2009) Manual de análises químicas de solos, plantas e fertilizantes. 2.ed. Brasília, Informação Tecnológica, 628 p.

Feizi M, Hajabbasi MA, Mostafazadeh-Fard B (2010) Saline irrigation water management strategies for better yield of safflower (Carthamus tinctorius L.) in an arid region. Aust $J$ Crop Sci. 4:408-414. 
Foloni JSS, Calonego JC, Lima SL (2003) Efeito da compactação do solo no desenvolvimento aéreo e radicular de cultivares de milho. Pesqui Agropecu Bras. 38:947-953

Foloni JSS, Lima SL, and Büll LT (2006) Crescimento aéreo e radicular da soja e de plantas de cobertura em camadas compactadas de solo. Rev Bras Ciênc Solo. 30:49-57.

Grzesiak S, Grzesiak MT, Hura T, Marcińska I, Rzepka A (2013) Changes in root system structure, leaf water potential and gas exchange of maize and triticale seedlings affected by soil compaction. Environ Exp Bot. 88:2-10.

Hargreaves GH, Samani ZA (1985) Reference crop evapotranspiration from temperature. Appl Eng Agric. 1:96-99.

Ilkılıç C, Aydın S, Behcet R, Aydin H (2011) Biodiesel from safflower oil and its application in a diesel engine. Fuel Process. Technol. 92: 356-362.

Movahhedy-Dehnavy M, Sanavy SAMM, Bidgoli AM (2009) Foliar application of zinc and manganese improves seed yield and quality of safflower (Carthamus tinctorius L.) grown under water deficit stress. Ind Crop Prod. 30:82-92.

Lima LB, Petter FA, Leandro WM (2015) Desempenho de plantas de cobertura sob níveis de compactação em Latossolo Vermelho de Cerrado. Rev Bras Eng Agr Amb. 19:1064-1071.

Nosalewicz A, Lipiec, J (2014) The effect of compacted soil layers on vertical root distribution and water uptake by wheat. Plant Soil. 375:229-240.

Paludo JTS, Bonfim-Silva EM, Silva TJA, Sousa HHF, Zanotto MD, Fenner W (2018) Agronomic performance of Safflower genotypes (Carthamus tinctorius L.) under different soil bulk density levels in the Oxisol of the Cerrado. Aust J Crop Sci. 12:407-412.

Paludo JTS, Bonfim-Silva EM, Silva TJA, Zanotto MD, Fenner W, Koetz M (2017) Reproductive components of safflower genotypes submitted of bulk density levels in the Brazilian Cerrado. Am J Plant Sci. 8:2069-2082.

Pfeifer J, Faget M, Walter A, Blossfeld S, Fiorani F, Schurr U, Nagel KA (2014) Spring barley shows dynamic compensatory root and shoot growth responses when exposed to localised soil compaction and fertilisation. Funct Plant Biol. 41:581-597.
Ramos JC, Imhoff SDC, Pilatti MÁ, Vegetti AC (2010) Morphological characteristics of soybean root apexes as indicators of soil compaction. Sci Agric. 67:707-712.

Reichert JM, Suzuki LEAS, Reinert DJ, Horn R, Håkansson I (2009) Reference bulk density and critical degree-ofcompactness for no-till crop production in subtropical highly weathered soils. Soil Till Res. 102:242-254.

Roque AAO, Souza ZM, Barbosa RS, Souza, GS (2010) Controle de tráfego agrícola e atributos físicos do solo em área cultivada com cana-de-açúcar. Pesqui. Agropecu. Bras. 45:744-750.

Rose TJ, Rengel Z, Ma Q, Bowden JW (2009) Crop species differ in root plasticity response to localised P supply. J Plant Nutr Soil Sci. 172:360-380.

Rosolem CA, Foloni JSS, Tiritan CS (2002) Root growth and nutrient accumulation in cover crops as affected by soil compaction. Soil Tillage Res. 65:109-115.

Santos RF, Bassegio D, Silva MA (2017) Yield and production components of safflower genotypes affected by irrigation at phenological stages. Agr Water Manage. 186:66-74.

Santos RF, Bassegio D, Silva MA, Klar AE, Silva, AAF, Silva, TRB (2018) Irrigated safflower at different phenological stages of Brazilian southeast dry season. Irriga. 23:493504.

Sarto MVM, Bassegio D, Rosolem CA, Sarto JRW (2018) Safflower root and shoot growth affected by soil compaction. Bragantia. 77:348-355.

Scapinelli A, Deina FR, Valadão Junior DD, Valadão FCA, Pereira LB (2016) Sistema radicular e componentes produtivos do girassol em solo compactado. Bragantia. 75:474-486.

Silva RH, Rosolem CA (2001) Crescimento radicular de espécies utilizadas como cobertura decorrente da compactação do solo. Rev. Bras. Ciênc. Solo. 25:253-260.

Valadão FCA, Weber OLS, Valadão Júnior DD, Scapinelli $A$, Deina FR, Bianchini A (2015) Adubação fosfatada e compactação do solo: sistema radicular da soja e do milho e atributos físicos do solo. Rev Bras Ciênc Solo. 39:243255. 